\title{
Dissolution behavior and phase evolution during aluminum oxide dissolution in BOF Slag
}

\author{
Gaurav Tripathi, Annelies Malfliet, Bart Blanpain, and Muxing Guo \\ Dept. of Materials Engineering, KU Leuven, Kasteelpark Arenberg 44 bus 2450, Leuven 3001, Belgium
}

\begin{abstract}
Basic oxygen furnace (BOF) slag is a byproduct in the steel making process and is produced in considerable amounts annually. Thus, the valorization of this slag is important. Additives such as $\mathrm{Al}_{2} \mathrm{O}_{3}$ can be utilized to modify the composition and mineralogy of the slag needed for its effective valorization provided that a fast and effective dissolution of these additives in molten slags can be ensured. With this in mind, the dissolution of $\mathrm{Al}_{2} \mathrm{O}_{3}$ particles in molten BOF slag has been investigated between 1500 and $1600{ }^{\circ} \mathrm{C}$. In all cases, a dissolution zone forms around the dissolving particle which limits the dissolution rate in the melt under natural convection conditions. The dissolution in the current system is found to be an indirect process, wherein crystalline reaction products like $\mathrm{CaAl}_{4} \mathrm{O}_{7}\left(\mathrm{CA}_{2}\right)$ and $\mathrm{CaAl}_{2} \mathrm{O}_{4}(\mathrm{CA})$ form on the surface of the particles. $\mathrm{CA}_{2}$ forms at $1600{ }^{\circ} \mathrm{C}$ and $\mathrm{CA}$ at $1500{ }^{\circ} \mathrm{C}$. These reaction products form a continuous layer on the surface of the dissolving particles but the impact of this layer on the dissolution process is not significant due to its limited thickness. The experimental data has been utilized to evaluate the dissolution paths. Near the $\mathrm{Al}_{2} \mathrm{O}_{3}$ /slag interface, the inter-diffusion of $\mathrm{Al}_{2} \mathrm{O}_{3}$ and $\mathrm{CaO}$ occurs due to which the dissolution path shifts towards the $\mathrm{Al}_{2} \mathrm{O}_{3}-\mathrm{CaO}$ binary system. A phenomenological model is presented to explain the evolution of the dissolution process in the current system, wherein, the kinetics of the process is used to explain the reaction products formed at 1600 and $1500{ }^{\circ} \mathrm{C}$. The rate of dissolution process is governed by the diffusion of species in the molten slag, especially in the dissolution zone.
\end{abstract}

\section{Introduction}

The annual production of steelmaking slags adds up to a huge quantity. Nearly 32.4 million tonnes and 326 million tonnes of steel slag was produced in EU and globally [1-2] respectively, during the year 2016. Basic Oxygen Furnace (BOF) slag makes up for nearly half of the steel slag produced in Europe [1]. Therefore, the valorization of BOF slag is essential.

The utilization of BOF slag for high added value products depends on the composition and mineralogy of the solidified slag. Hot stage slag engineering is an effective way to change the properties of the slag in the liquid state in order to control the properties of the solidified slag without affecting the quality of the steel being produced during the steelmaking process [31]. One of the preferred ways is to undertake this step after slag has already been transferred in the slag pot during the convertor process. The hot stage engineering can involve processes such as the addition of slag modifiers such as $\mathrm{Al}_{2} \mathrm{O}_{3}$ or $\mathrm{SiO}_{2}$ to the slag. These additions are done in order to achieve a desired mineralogy and for the stabilization of specific minerals in the slag. The presence of free $\mathrm{CaO}$ or $\mathrm{MgO}$ can lead to volume instability of the slag, as these phases tend to undergo expansive hydration [3]. The modifiers added in the slag, after dissolution, can react with these unstable phases, thereby stabilizing the solidified slag. Hot stage engineering can also involve introducing additives to facilitate the faster dissolution of the added slag modifiers and the separation of the metallic phases from the slag.

The dissolution rate of solids into fluids has been studied from many perspectives. In the fields of materials and chemical engineering, dissolution has been studied related to leaching of metal ores, absorption or the dissolution of oxide inclusions for clean steel production, refractory corrosion etc. [4-13]. The dissolution of solid oxides into molten slags has been studied extensively. The rotating finger setup has been employed to study the kinetics of dissolution into a variety of slags [4-6, 18-23]. Nakashima et al. studied the dissolution of $\mathrm{Al}_{2} \mathrm{O}_{3}$ in Blast Furnace (BF) and soda slag using the rotating finger method in the range of 1400 to $1600{ }^{\circ} \mathrm{C}$ [4]. Yu et al. used a similar setup to study the $\mathrm{Al}_{2} \mathrm{O}_{3}$ dissolution in mold fluxes [5]. Amini et al. [6] studied the dissolution of $\mathrm{CaO}$ in synthetic silicate slags with the additions of composition modifiers like $\mathrm{SiO}_{2}, \mathrm{Fe}_{\mathrm{x}} \mathrm{O}, \mathrm{CaF}_{2}$. Confocal Scanning Laser Microscopy (CSLM) has also been used as a powerful tool for in-situ observation of the dissolution process in a 
variety of slags [7-13]. The present study utilizes a setup which enables us to mimic the industrial treatment of BOF slag. According to previous studies [14-19], dissolution may involve the formation of an intermediate reaction product. This type of dissolution is referred to as indirect dissolution. Sandhage et al. [18] found that spinel $\left(\mathrm{MgAl}_{2} \mathrm{O}_{4}\right)$ formed at the $\mathrm{Al}_{2} \mathrm{O}_{3} / \mathrm{CaO}-\mathrm{SiO}_{2}-\mathrm{Al}_{2} \mathrm{O}_{3}-\mathrm{MgO}$ melt interface. Oishi et al. [23] reported layers of $\mathrm{CaAl}_{4} \mathrm{O}_{7}$ and $\mathrm{CaAl}_{12} \mathrm{O}_{19}$ near the sapphire/CaO-SiO${ }_{2}-\mathrm{Al}_{2} \mathrm{O}_{3}$ melt interface. The dissolution behavior of oxide particles (e.g. $\mathrm{Al}_{2} \mathrm{O}_{3}, \mathrm{SiO}_{2}$ ) in high basicity slags with $\mathrm{CaO}$-saturation and high $\mathrm{FeO}_{\mathrm{x}}$ slags has not been investigated.

The objective of this study is to investigate the dissolution of $\mathrm{Al}_{2} \mathrm{O}_{3}$ particles in an industrial BOF slag and clearly evaluate the following things: (i) The rate of dissolution (ii) The reactions and additional phases (if any) formed during the dissolution process, (iii) The dissolution paths and (iv) The diffusion coefficient of $\mathrm{Al}_{2} \mathrm{O}_{3}$ in the slag. The experiments have been conducted between 1500 and $1600{ }^{\circ} \mathrm{C}$.

\section{Experimental method}

\subsection{Materials preparation}

The dissolution experiments were performed using industrial BOF slag (Table 1) and $\mathrm{Al}_{2} \mathrm{O}_{3}$ spheres (>98\% purity) supplied by Sasol. The distribution of the particles' diameter was obtained using scanning electron microscope imaging (SEM) and thereafter ImageJ software (Figure 1).

Table 1. Composition (wt $\%$ ) of the industrial BOF slag used for the experiments.

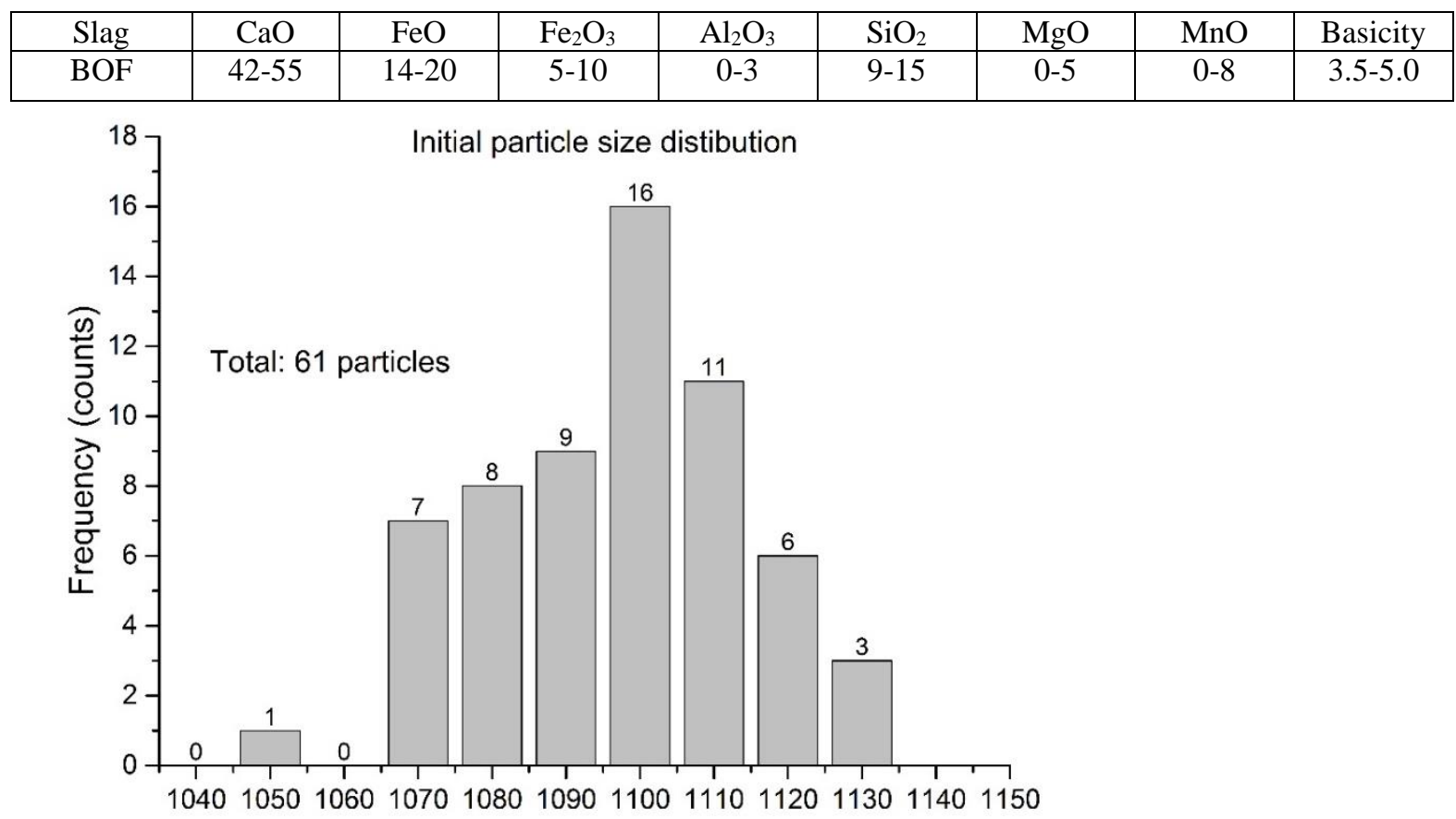

Particle size $(\mu \mathrm{m})$

Figure 1. Initial size (diameter) distribution of the $\mathrm{Al}_{2} \mathrm{O}_{3}$ particles (spheres).

\subsection{Experimental setup and procedure}

The schematic diagram of the used apparatus is shown in Figure 2. This vertical furnace setup enables the addition of particles to slag at high temperature. Around 50-70 grams of powdered slag was placed in a molybdenum crucible (inside diameter $=40 \mathrm{~mm}$; height $=40 \mathrm{~mm}$; thickness $=5 \mathrm{~mm}$ ) and heated in a resistance furnace (GERO HTRV, $\mathrm{MoSi}_{2}$ heating elements). A purified stream of Argon gas (passed through silica gel and a furnace containing $\mathrm{Mg}$ turnings operated at $500{ }^{\circ} \mathrm{C}$ to remove traces of moisture and oxygen) was blown into the furnace at a flow rate of around $0.3 \mathrm{~L} / \mathrm{min}$. The system was flushed for an hour and the furnace was heated up at a rate of $5{ }^{\circ} \mathrm{C} / \mathrm{min}$. The oxygen partial pressure in the furnace was constantly monitored using the Rapidox 2100 portable zirconia oxygen gas analyzer. After having reached the desired temperature (Table 2) for one hour to ensure the 
homogeneity of the molten slag, $\mathrm{Al}_{2} \mathrm{O}_{3}$ spheres (amount of about $5 \mathrm{wt} \%$ of the slag) were added to the slag. The crucible was taken out of the furnace after the targeted holding time and quenched with water. The quenched slag was drilled out of the crucible for further analysis.

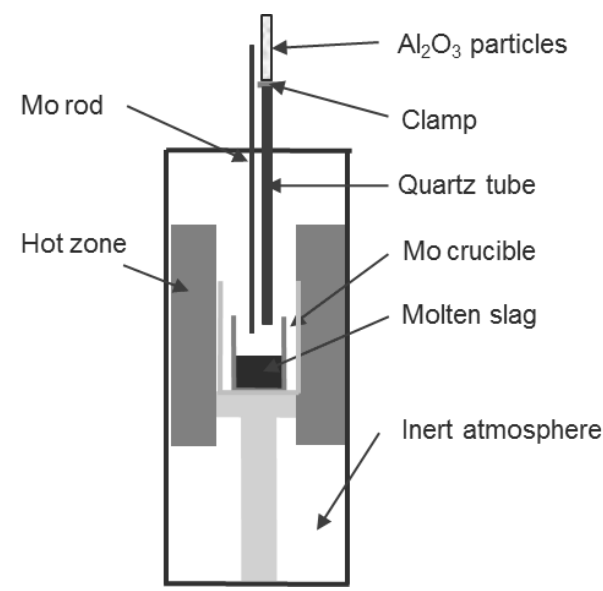

Figure 2. Experimental setup for the dissolution tests.

Table 2. Summary of the experimental conditions.

\begin{tabular}{|c|c|c|l|}
\hline Experiment & Temperature $\left({ }^{\circ} \mathrm{C}\right)$ & Quenching after $(\mathrm{s})$ & Others \\
\hline 1 & 1600 & \multirow{2}{*}{$60,120,180$} & \multirow{2}{*}{$\begin{array}{l}\text { Additions=5 wt. } \% \\
\text { Slag }=50 \sim 70 \mathrm{~g}\end{array}$} \\
\hline 2 & 1580 & & \\
\hline 4 & 1550 & 180,300 & \\
\hline
\end{tabular}

\subsection{Sample analysis}

The drilled out slag was embedded in a low viscosity resin (Epofix), ground with silicon carbide grinding papers and polished with diamond slurry. The polished samples were carbon coated for compositional and microstructural analyses. Compositional analyses were performed with a full quantitative Electron Probe X-ray Micro Analysis coupled with Wavelength Dispersive Spectroscopy (EPMA-WDS, JEOL JXA-8530F). The microprobe was operated using an acceleration voltage of $15 \mathrm{kV}$ and a probe current of $15 \mathrm{nA}$. Corundum $\left(\mathrm{Al}_{2} \mathrm{O}_{3}\right)$, fluorite $\left(\mathrm{CaF}_{2}\right)$, hematite $\left(\mathrm{Fe}_{2} \mathrm{O}_{3}\right)$, quartz $\left(\mathrm{SiO}_{2}\right)$ and periclase $(\mathrm{MgO})$ were used as standard samples.

The quantitative line analysis was done in several directions around the dissolving particle and then the measurements were grouped together in one dataset for further considerations. For each sample, the particle with the biggest diameter in the cross section was selected for the quantitative analysis assuming that the cross-section is closest to the plane passing through the center of the particle.

All the measured points on the slag phase within $50 \mu \mathrm{m}$ from the particle /slag interface were measured as an accumulation of a set of three points ( $2 \mu \mathrm{m}$ from each other separated). Farther than $50 \mu \mathrm{m}$ from the interface an electron beam diameter of $2 \mu \mathrm{m}$ was used. This was preferred instead of a point as the slag was separated in several phases upon cooling down and the aim was to measure the global $\mathrm{Al}_{2} \mathrm{O}_{3}$ content.

\subsection{Thermodynamic Calculations}

The thermodynamic software FactSage ${ }^{\mathrm{TM}}$ was used to calculate the phase equilibria in $\mathrm{CaO}-\mathrm{Al}_{2} \mathrm{O}_{3}-\mathrm{Fe}_{3} \mathrm{O}_{4}$ system. This system represents the major components of the slag in proximity of the dissolving particle as will be shown in later discussions. Isothermal sections at $1600{ }^{\circ} \mathrm{C}$ and $1500{ }^{\circ} \mathrm{C}$ were calculated at an oxygen partial pressure $\mathrm{pO}_{2}$ of $10^{-10}$ atm reflecting the experimental atmospheric condition used to maintain the iron oxide content in the slag and to prevent the oxidation of the molybdenum crucibles. The phase diagram module of the software and the FTPS and FToxid databases were used for the calculations. The work on the $\mathrm{Al}_{2} \mathrm{O}_{3}-\mathrm{CaO}-\mathrm{FeO}-\mathrm{Fe}_{2} \mathrm{O}_{3}$ phase equilibria by Imlach and Glasser [27] was used for the validation of these calculations. They have reported the liquid surfaces in the $\mathrm{Al}_{2} \mathrm{O}_{3}-\mathrm{CaO}-\mathrm{FeO}_{\mathrm{x}}$ system in air and $\mathrm{pO}_{2}=10^{-5}$ and $10^{-8}$ atm. 


\section{Results and discussion}

\subsection{Formation of dissolution zone}

The samples from experiments conducted at four different temperatures (Table 2) were analyzed. The results presented are from the experiments conducted at 1600 and $1500{ }^{\circ} \mathrm{C}$ as they give a complete picture of the dissolution process and highlight the effects of different parameters on the process. In all cases, an $\mathrm{Al}_{2} \mathrm{O}_{3}$-rich zone forms in the vicinity of the particles (Figure 3,4) and contains precipitated crystalline phases. The size of this zone and of the phases within increase with increasing time and temperature. The long axis of the elongated crystalline phases has the same direction as the flux flow of the species in the molten slag, i.e. perpendicular to the interface of the dissolving particle. The directional growth of these phases will be further explained and discussed later when the overall schematics of the dissolution process are discussed.

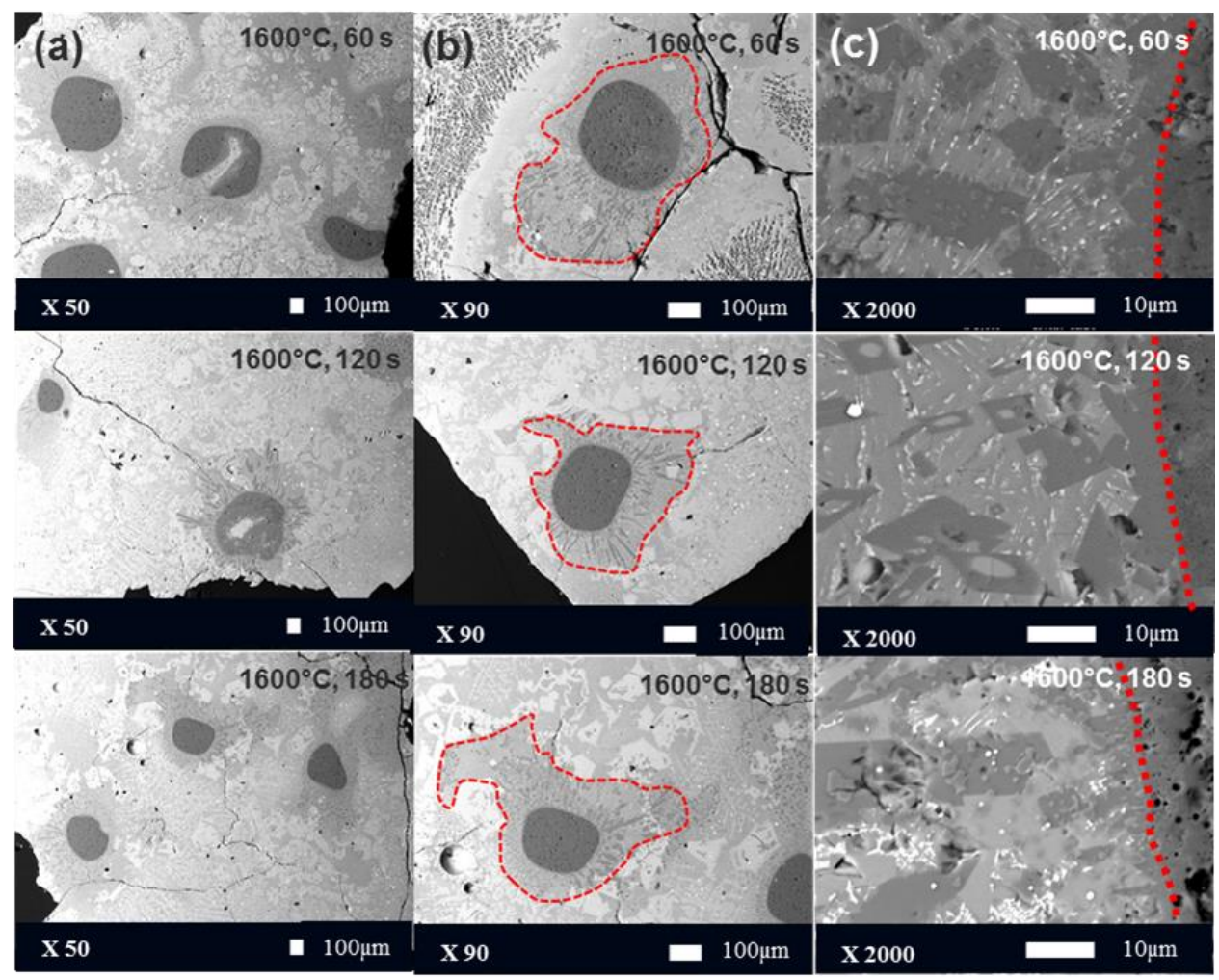

Figure 3 BSE images from the samples quenched at $1600{ }^{\circ} \mathbf{C}$ showing: a) General overview 60,120 and $180 \mathrm{~s}$ after particle addition; b) $\mathrm{Al}_{2} \mathrm{O}_{3}$ rich zones around the particle (highlighted by red boundaries) and precipitated phases within after 60,120 and $180 \mathrm{~s}$; c) Interface (dotted red line) of $\mathrm{Al}_{2} \mathrm{O}_{3}$ particle with the slag after 60,120 or $180 \mathrm{~s}$, showing a uniformly covered interface and precipitates in the vicinity.

Under static dissolution, the added particles form clusters in the molten slag at $1500{ }^{\circ} \mathrm{C}$ (Figure 5 (a)). This effect is non-evident at higher temperature. The dissolving particles in the formed clusters interact (Figure 5(b)). This interaction can have negative implications on the dissolution rate as the local driving force for the $\mathrm{Al}_{2} \mathrm{O}_{3}$ dissolution is reduced. Hence, the formation of clusters must be avoided for faster dissolution. One effective way can be the introduction of dynamic conditions i.e. stirring the sample after the addition of particles. 

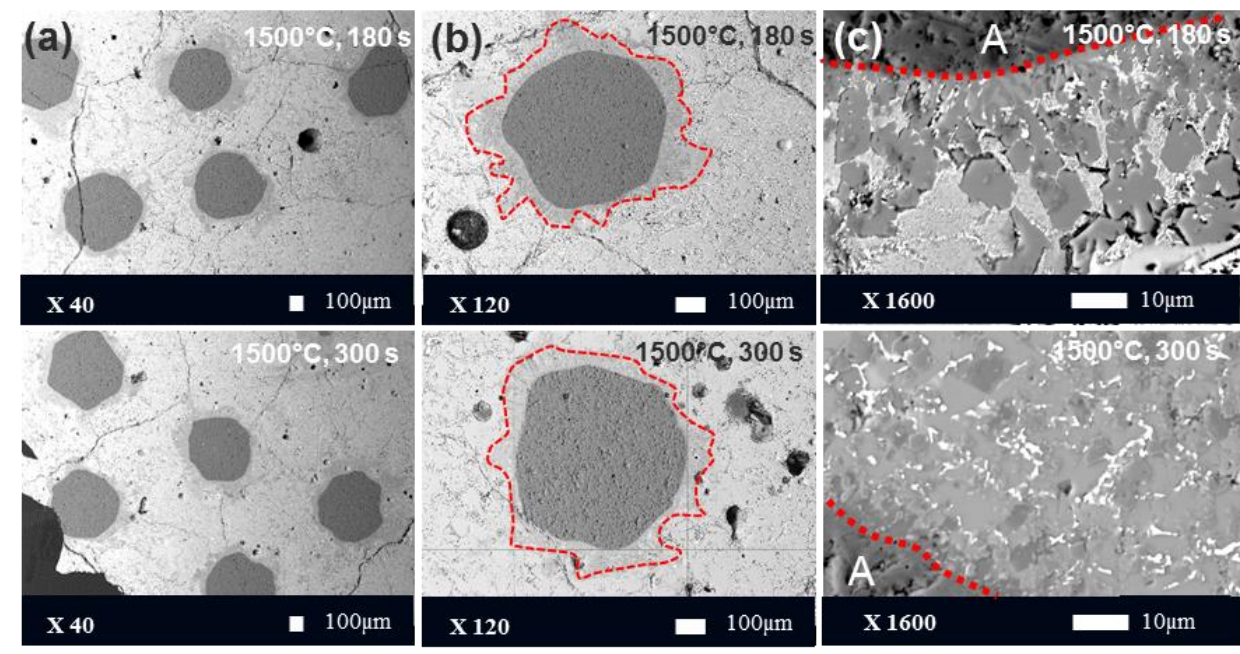

Figure 4 BSE images from the samples quenched at $1500{ }^{\circ} \mathbf{C}$ showing: a) General overview 180 and $300 \mathrm{~s}$ after particle addition; b) $\mathrm{Al}_{2} \mathrm{O}_{3}$ rich zones around the particle (highlighted by red boundaries) after 180 and $300 \mathrm{~s} ; \mathrm{c}$ ) Interface (dotted red line) of $\mathrm{Al}_{2} \mathrm{O}_{3}$ particle with the slag after 180 and $300 \mathrm{~s}$.

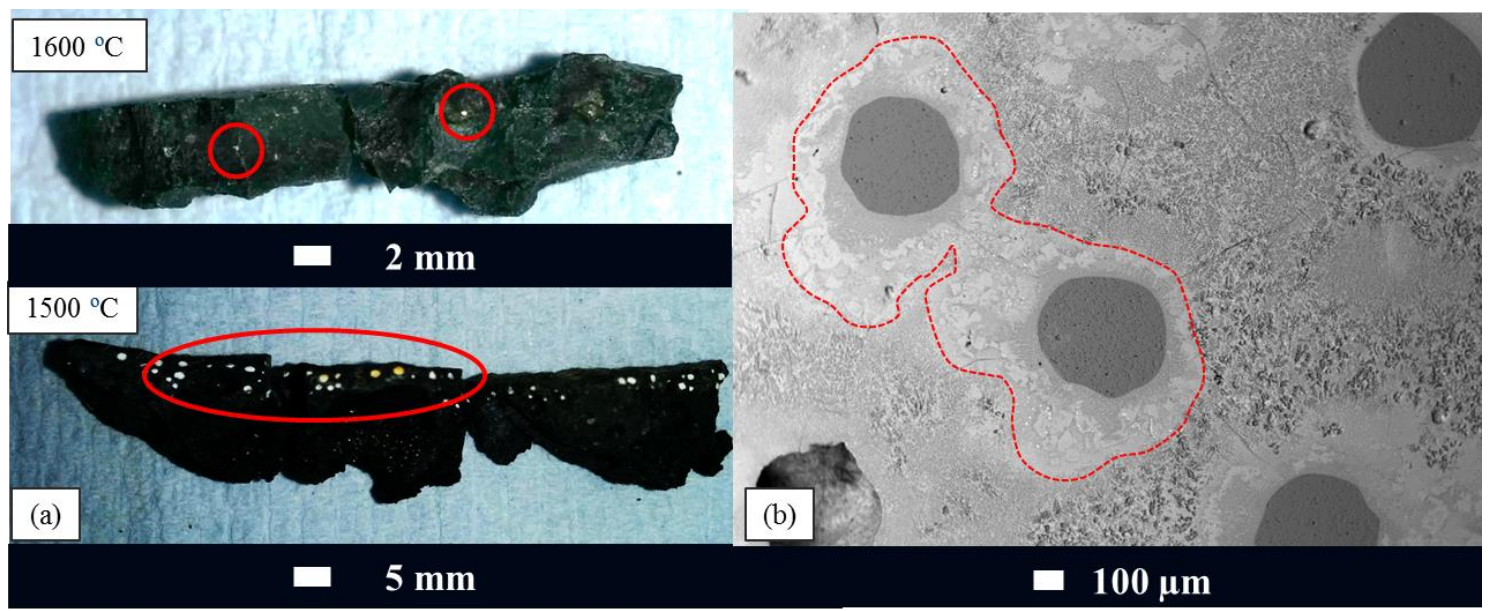

Figure 5 (a) Slag samples showing the clustering of added particles in the slag at $1500{ }^{\circ} \mathrm{C}$, this is not observed at $1600{ }^{\circ} \mathrm{C}$ (b) Micrograph showing the interaction (highlighted) in the cluster of dissolving particles.

\subsection{Reaction products at the $\mathrm{Al}_{2} \mathrm{O}_{3}$ particle/slag interface}

$\mathrm{Al}_{2} \mathrm{O}_{3}-\mathrm{CaO}$ reaction products form in all samples at the $\mathrm{Al}_{2} \mathrm{O}_{3} /$ slag interface, but their morphology and type depend on the temperature. A continuous layer of $\mathrm{CA}_{2}\left(\mathrm{CaAl}_{4} \mathrm{O}_{7}\right)$ surrounds the partially dissolved particle at 1600 ${ }^{\circ} \mathrm{C}$ (Figures 6), whereas at $1500{ }^{\circ} \mathrm{C}, \mathrm{CA}\left(\mathrm{CaAl}_{2} \mathrm{O}_{4}\right)$ is the main constituent of the interfacial layer with a small amount of $\mathrm{CA}_{2}$ between this layer and the particle (Figure 7(b)). No formation of $\mathrm{CA}_{6}$ was observed. Due to the phase separation involved during quenching it is important to distinguish the phases precipitating in the slag at high temperature and those appearing during the solidification. The phase stabilities in the system at concerned temperature can provide insights into this question. Thus, The isothermal sections of the $\mathrm{CaO}-\mathrm{Al}_{2} \mathrm{O}_{3}-\mathrm{Fe}_{3} \mathrm{O}_{4}$ system were calculated (Figure 9). This slag was considered for simplification. This is a fair approximation especially in the vicinity of dissolving particle where $\mathrm{CaO}, \mathrm{Al}_{2} \mathrm{O}_{3}$ and $\mathrm{Fe}_{3} \mathrm{O}_{4}$ were confirmed as the major components through chemical analysis.

The straight line connecting the bulk slag composition (represented as star) and $\mathrm{Al}_{2} \mathrm{O}_{3}$ corner of the ternary system passes through the two phase region liquid $+\mathrm{CA}_{2}$. This is reflected in the microstructure at the $\mathrm{Al}_{2} \mathrm{O}_{3} / \mathrm{slag}$ interface at $1600{ }^{\circ} \mathrm{C}$. The formation of solid CA phase at this temperature is thermodynamically not favorable. At $1500{ }^{\circ} \mathrm{C}$ the straight line still passes through the two phase region liquid+CA $\mathrm{C}_{2}$. However, the interface microstructure shows that CA phase predominantly gets formed at this temperature. 


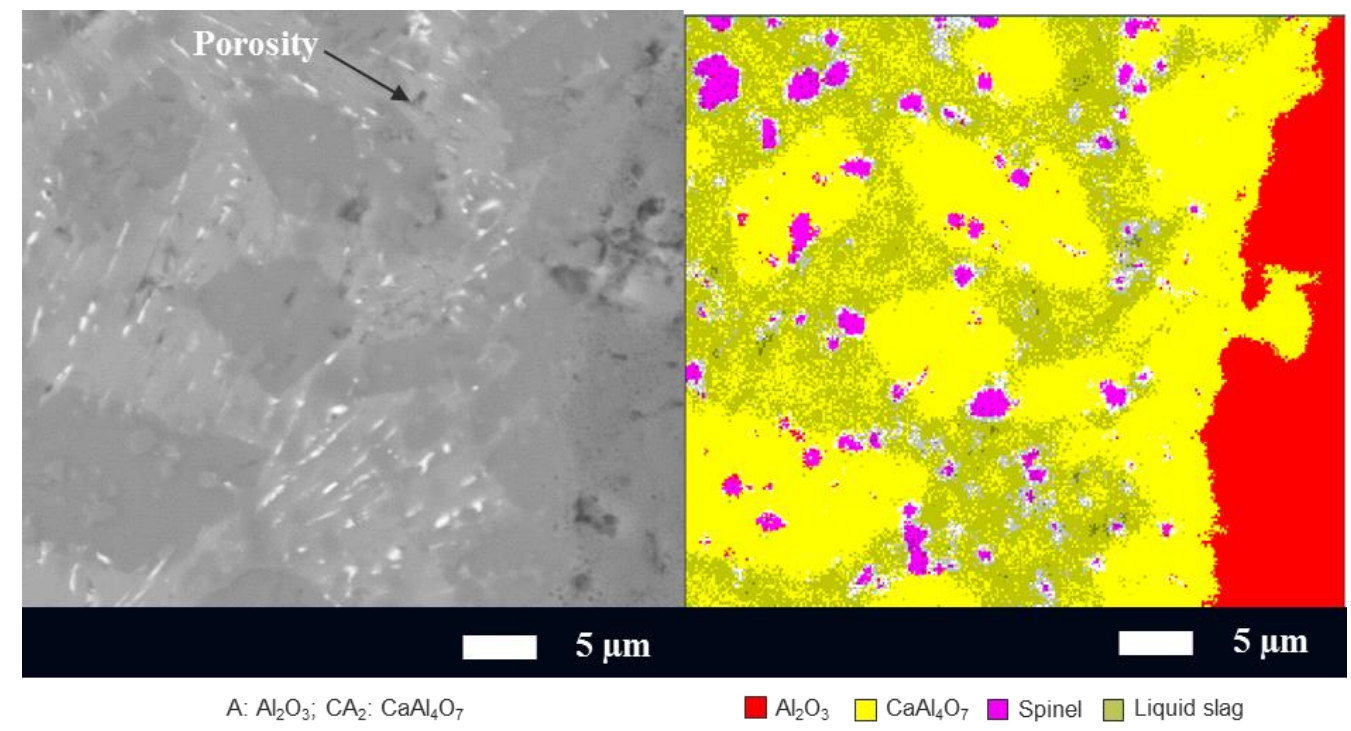

Figure $6 \mathrm{BSE}$ image of $\mathrm{Al}_{2} \mathrm{O}_{3} / \mathrm{slag}$ interface at $1600{ }^{\circ} \mathrm{C}$ for the sample quenched $60 \mathrm{~s}$ after the addition; showing $\mathrm{Al}_{2} \mathrm{O}_{3}, \mathrm{CA}_{2}$ and slag. The tiny black spots are porosities in the matrix and corresponding phase map based on EPMA-WDS elemental mapping confirming the presence of $\mathrm{CaAl}_{4} \mathrm{O}_{7}$ at the interface. Spinel $\left(\mathrm{MgAlO}_{4}\right)$ formation in the vicinity was also observed.

Although the dissolution path was discussed in context of a straight line joining the starting compositions in the past [7], the dissolution is a non-equilibrium process and the difference in the mobility of species present in a multi-component system causes the divergence of the diffusion path from straight line. Preferential formation of $\mathrm{CA}$ to $\mathrm{CA}_{2}$ cannot be explained just by thermodynamic considerations. The formation of these products will be discussed from the kinetic aspects in the following sections. 

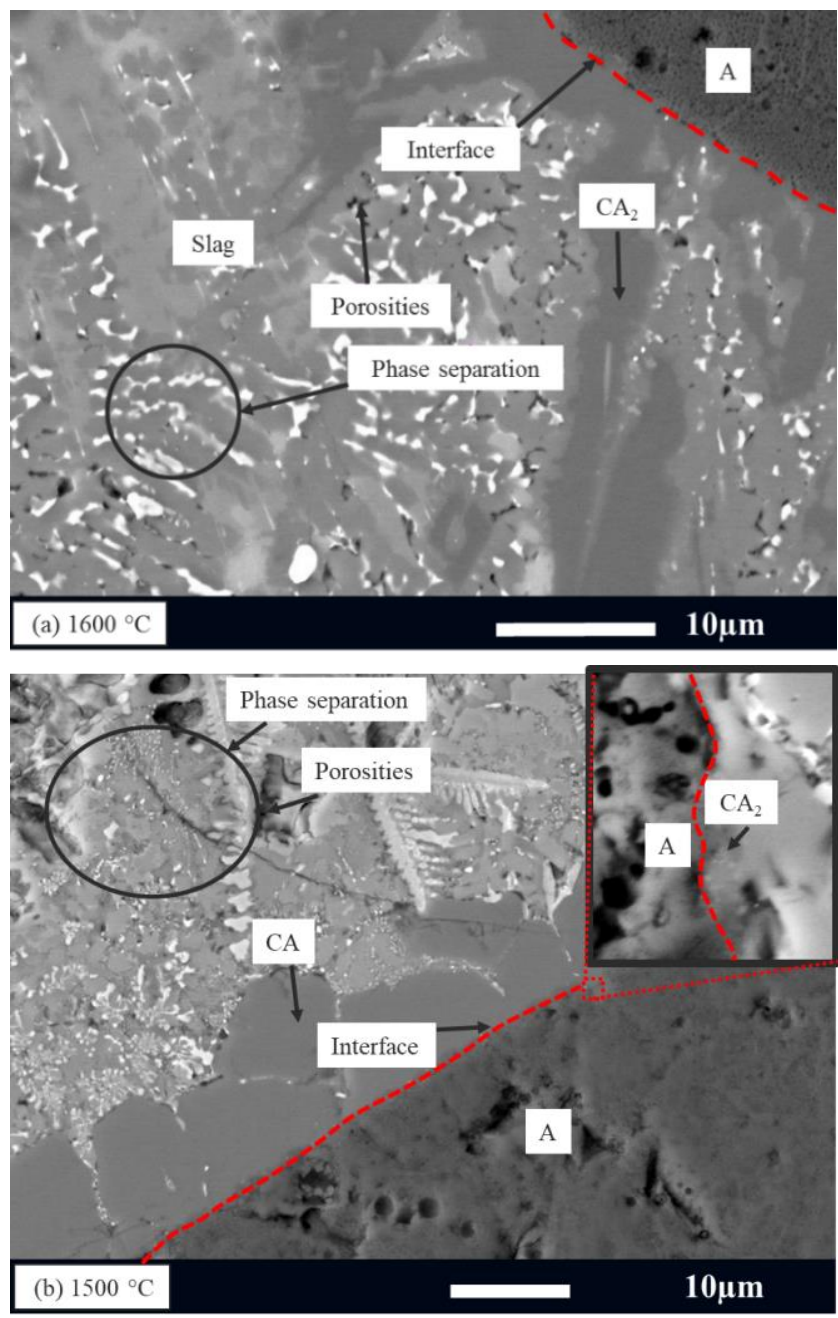

Figure 7 The reaction products formed at the $\mathrm{Al}_{2} \mathrm{O}_{3} / \mathrm{slag}$ interface (a) at $1600{ }^{\circ} \mathrm{C}$ (b) at $1500{ }^{\circ} \mathrm{C}$. C: $\mathrm{CaO}, \mathrm{A}: \mathrm{Al}_{2} \mathrm{O}_{3}$. The $\mathrm{Al}_{2} \mathrm{O}_{3}$ interface is shown by a red dashed line, Magnified view of the interface (enclosed by dotted lines) showing small precipitates of $\mathrm{CA}_{2}$ at the interface.

\subsection{Dissolution path}

Dissolution path is a line on the ternary isotherm of a system, representing the locus of the average compositions in the planes parallel to the original interface through the diffusion zone [28]. Kirkaldy and Brown [29] performed several experiments with diffusion couples and formulated a number of rules which relate the composition of the diffusion zone with the phase diagram. The rules for paths containing two-phase regions and non-planar interfaces have been utilized in the present study.

The normalized concentration profiles for different species from the particle/slag interface towards the bulk slag measured in three directions are compiled in Figure 8 for a sample quenched 60 seconds after particle addition. The $\mathrm{Al}_{2} \mathrm{O}_{3}$ concentration reduces steadily and a simultaneous counter-current diffusion of $\mathrm{CaO}$ takes place. The $\mathrm{Fe}_{\mathrm{x}} \mathrm{O}$ content increases steadily and an $\mathrm{Al}_{2} \mathrm{O}_{3}$ enriched zone is formed around the dissolving particle. It is in this zone that the $\mathrm{Al}_{2} \mathrm{O}_{3}-\mathrm{CaO}$ crystalline phases are formed (Figure 3). Dissolution paths obtained from this data are shown in Figure 9. As mentioned before, inter-diffusion of $\mathrm{Al}_{2} \mathrm{O}_{3}$ and $\mathrm{CaO}$ is observed near the interface, which explains the shift of the path towards the $\mathrm{Al}_{2} \mathrm{O}_{3}-\mathrm{CaO}$ binary. This shift gets prominent as the dissolution process continues (Figure 9 (a)\&(b)). At $1500{ }^{\circ} \mathrm{C}$ a less prominent shift towards the $\mathrm{Al}_{2} \mathrm{O}_{3}-\mathrm{CaO}$ binary is observed. As the dissolution path reaches the liquid solid interface, it passes through a 2 phase $\left(\mathrm{L}+\mathrm{CA}_{2}\right.$ or $\left.\mathrm{L}+\mathrm{CA}\right)$ region and a non-planar boundary between liquid and solid, thus the path crosses this region across the tie-lines. The solidsolid interface between the $\mathrm{Al}_{2} \mathrm{O}_{3}$ and reaction products is planar and thus the path connects these points along the tie-line in the binary system. 


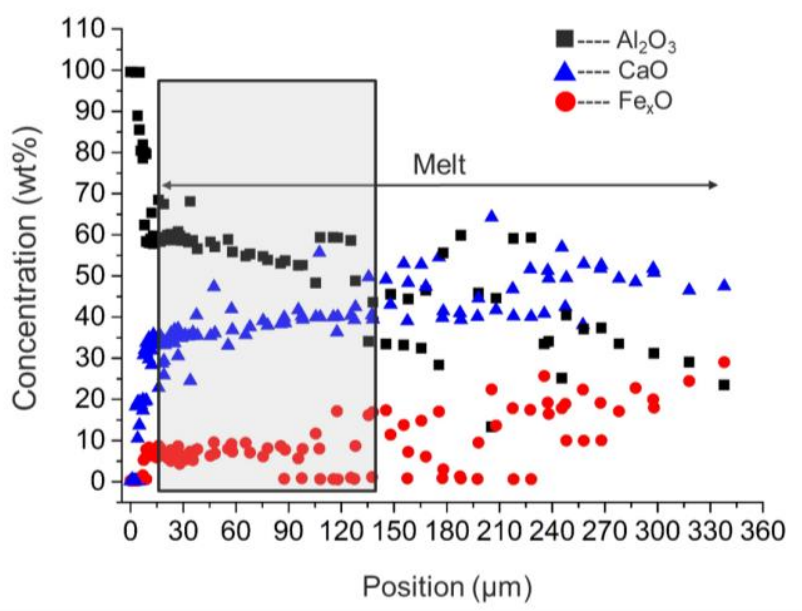

Figure 8 The distribution of $\mathrm{Al}_{2} \mathrm{O}_{3}, \mathrm{CaO}$ and $\mathrm{Fe}_{\mathrm{X}} \mathrm{O}$ near the $\mathrm{Al}_{2} \mathrm{O}_{3}$ /slag interface as measured by WDS . The shaded part highlights the $\mathrm{Al}_{2} \mathrm{O}_{3}$ rich zone previous shown in Figure 3(b) \& 4(b). 

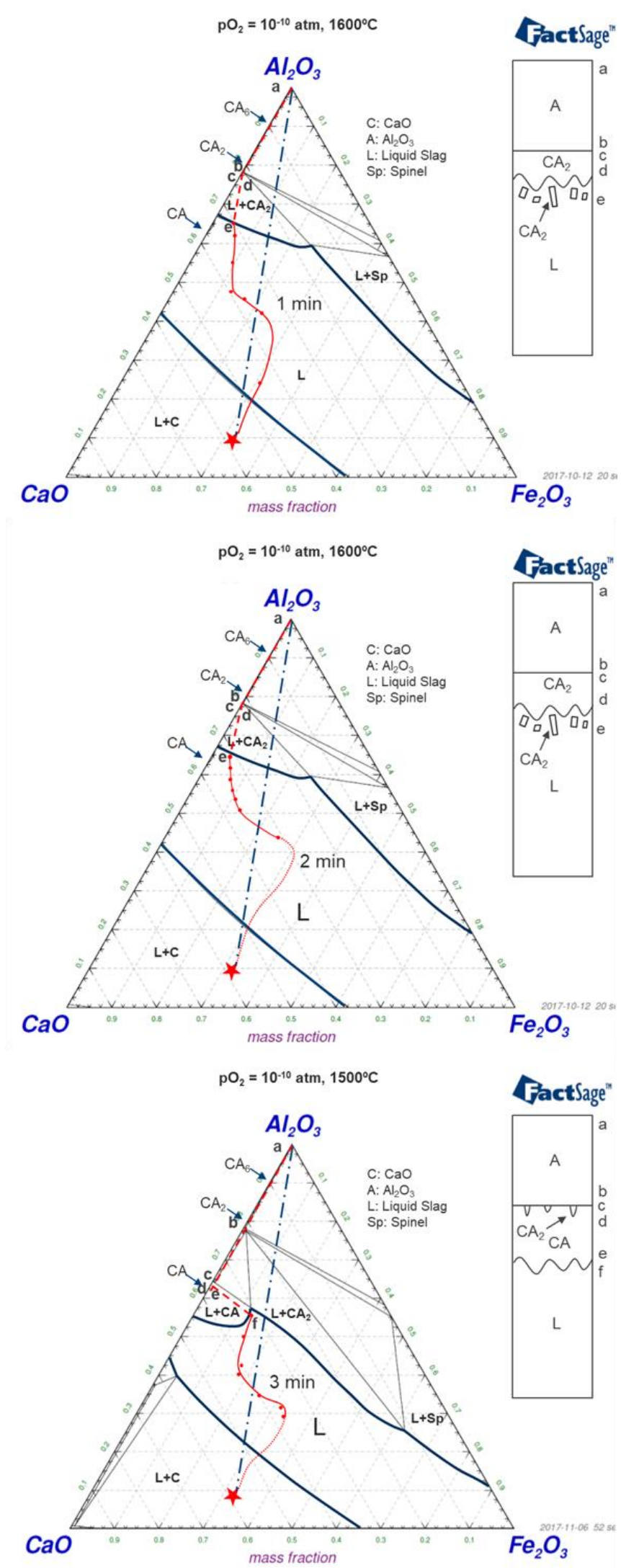

Figure 9 Isothermal sections showing the dissolution paths $1600(60 \mathrm{~s}$ in $9(\mathrm{a}), 120 \mathrm{~s}$ in $9(\mathrm{~b}))$ and $1500{ }^{\circ} \mathrm{C}(180 \mathrm{~s}$ in $9(\mathrm{c}))$. Star shows the starting slag composition. In the liquid region: Solid part of the lines depict measured paths and dotted part show the estimation based on mass balance. In the solid and two phase regions paths are shown by dashed lines. 
To further clarify the dissolution mechanisms, a phenomenological model based on the experimental observations is presented here. Besides the thermodynamic equilibria as discussed in previous sections, this model takes kinetics into account to describe the formation of phases and their growth. The following is assumed:

1. The initial localized drop in temperature from the addition of the particles (at room temperature) to the molten slag can be neglected. A drop in temperature can have a significant impact on the initial dissolution rate, but given the small amount of slag sample and constant heat input, the effect of this initial heat drop is negligible. This is different from the industrial conditions where, after tapping the molten slag from the convertor, a constant heat loss is involved.

2. The formation rate of reaction products is fast. This means that local equilibrium is instantly reached.

3. The transport of $\mathrm{Al}^{3+}$ and $\mathrm{Ca}^{2+}$ ions in the molten slag can be treated as the transport of $\mathrm{Al}_{2} \mathrm{O}_{3}$ and $\mathrm{CaO}$. This is a reasonable assumption as the diffusion of $\mathrm{O}^{2-}$ ions is one order faster than the diffusion of $\mathrm{Al}^{3+}{\mathrm{Or} \mathrm{Ca}^{2+}}^{2+}$ ions [30].

4. At the $\mathrm{Al}_{2} \mathrm{O}_{3} /$ slag interface, the reactions products form through the dissolution of $\mathrm{Al}_{2} \mathrm{O}_{3}$ in the liquid and the consequent reaction with $\mathrm{CaO}$.

5. The particles are spherical in shape (throughout the process) with some surface irregularities.

6. Each particle dissolves independently. Hence, The interaction of the concerned particle with other dissolving particles in the vicinity is neglected.

The overall schematic diagram is shown in Figure 11. The changes in particle size with time are shown. The dashed circle indicates initial particle size, blue circle is the $\mathrm{Al}_{2} \mathrm{O}_{3}$ particle, orange zone is the molten slag, grey region shows the extent to which $\mathrm{Al}_{2} \mathrm{O}_{3}$ has diffused in the slag and light blue hashed zones depict the formed reaction products. The blue arrows show $\mathrm{Al}_{2} \mathrm{O}_{3}$ flux away from the interface and black arrows show $\mathrm{CaO}$ flux in the opposite direction.

Once the particles are added $\mathrm{Al}_{2} \mathrm{O}_{3}$ dissolves directly into the molten slag. As the saturation for $\mathrm{CA}_{2}$ is reached, $\mathrm{CaO}$ in slag combines with the dissolved $\mathrm{Al}_{2} \mathrm{O}_{3}$ and $\mathrm{CA}_{2}$ phase nucleates on the particle interface. The precipitation of $\mathrm{CA}_{2}$ consumes $\mathrm{CaO}$ locally, which leads to an influx of $\mathrm{CaO}$ to the interface. The nucleation of $\mathrm{CA}_{2}$ and the growth of these nuclei at the interface leads to an interface which is covered by a continuous layer of $\mathrm{CA}_{2}$. Continued dissolution of $\mathrm{Al}_{2} \mathrm{O}_{3}$ and its transport away from the particle leads to the expansion of the $\mathrm{Al}_{2} \mathrm{O}_{3}$ rich zone farther away from the interface. This facilitates the precipitation of $\mathrm{CA}_{2}$ phases not only at the interface but farther away from it as well. The growth of the formed reaction layer is however limited. This growth depends on the flux of $\mathrm{Al}_{2} \mathrm{O}_{3}$ through the reaction layer to the liquid and the influx of $\mathrm{CaO}$ to this $\mathrm{CA}_{2} /$ slag interface. The nucleation of $\mathrm{CA}_{2}$ phases away from the interface consumes the $\mathrm{CaO}$ influx before it reaches the reaction layer, thus limiting the growth of this layer. $\mathrm{CA}_{2}$ phases nucleated away from the interface keep on growing at the expense of the layer. The growth of these precipitated phases is roughly perpendicular to the interface occurs along the direction of influx of $\mathrm{CaO}$ from the bulk slag (Figure 3).

Both $\mathrm{CA}_{2}$ and $\mathrm{CA}$ phases are thermodynamically stable at $1500{ }^{\circ} \mathrm{C}$. The dissolution rate, however, is reduced at the lower temperature which reduces the $\mathrm{Al}_{2} \mathrm{O}_{3}$ influx into the slag. The initial precipitation of small amount of $\mathrm{CA}_{2}$, as was seen in Figure 9(b), reduces both the dissolved $\mathrm{Al}_{2} \mathrm{O}_{3}$ and local $\mathrm{CaO}$ content in the slag. This shifts the slag composition in the CA stability region leading to the preferential formation of CA (see Figure 9) .

Thus, even though dissolution of $\mathrm{Al}_{2} \mathrm{O}_{3}$ in $\mathrm{BOF}$ slag is an indirect dissolution process, it has an insignificant effect on the overall dissolution rate due to the relatively limited thickness of the interfacial reaction layer. The presence of a significant gradient of $\mathrm{Al}_{2} \mathrm{O}_{3}$ in slag near the interface and the formation of precipitates indicates that the transport of species in the slag controls the overall dissolution rate. 


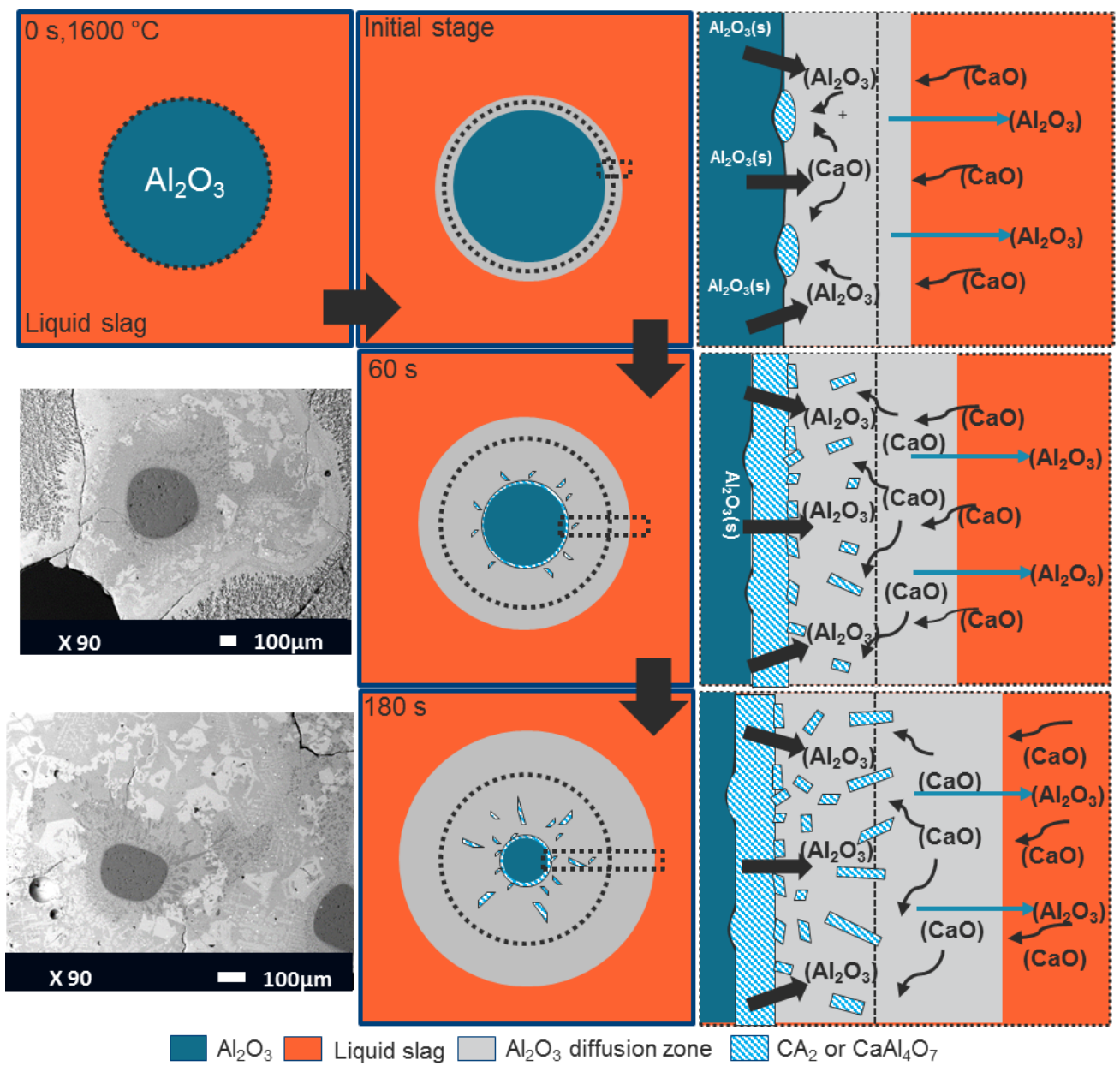

Figure 10 Evolution of the dissolution process over time.

\section{Conclusions}

The dissolution of $\mathrm{Al}_{2} \mathrm{O}_{3}$ particles in molten $\mathrm{BOF}$ slag was investigated between 1500 and $1600{ }^{\circ} \mathrm{C}$. The formation of a dissolution zone around the dissolving particle under the natural convection conditions limits the dissolution rate. This is due to the high viscosity the slag which limits the diffusion of $\mathrm{Al}_{2} \mathrm{O}_{3}$ especially at lower temperatures.

The dissolution of particles in slag was found to be an indirect dissolution process, wherein $\mathrm{Al}_{2} \mathrm{O}_{3}-\mathrm{CaO}$ crystalline reaction products like $\mathrm{CaAl}_{4} \mathrm{O}_{7}\left(\mathrm{CA}_{2}\right)$ and $\mathrm{CaAl}_{2} \mathrm{O}_{4}(\mathrm{CA})$ are formed on the surface of the particles i.e. at the $\mathrm{Al}_{2} \mathrm{O}_{3} / \mathrm{slag}$ interface. A continuous layer of these products was formed at the interface. The experimental data was used to evaluate the dissolution paths. It was found that near the $\mathrm{Al}_{2} \mathrm{O}_{3} /$ slag interface the inter-diffusion of $\mathrm{Al}_{2} \mathrm{O}_{3}$ and $\mathrm{CaO}$ is the predominant phenomenon. The dissolution path shifts towards the $\mathrm{Al}_{2} \mathrm{O}_{3}-\mathrm{CaO}$ binary system as we move from the bulk slag towards the interface.

A phenomenological model was presented to explain the evolution of the dissolution process, wherein, the kinetics of the dissolution process was used to explain the reaction products formed. The shift from $\mathrm{CA}_{2}$ formed at $1600{ }^{\circ} \mathrm{C}$ to $\mathrm{CA}$ at $1500{ }^{\circ} \mathrm{C}$ was also discussed. The reaction products formed a continuous layer on the surface of the dissolving particles but their thickness remained limited and hence did not have a significant impact on the overall dissolution process. The rate of dissolution process was found to be governed by the diffusion of species in the slag, more prominently in the dissolution zone. 


\section{Acknowledgments}

The authors gratefully acknowledge and thank the financial support from ArcelorMittal Gent which was crucial for this work.

\section{Literature Cited}

[1] ISSI(2015): WORLD STEEL ASSOCIATION - Statistics, https://www.worldsteel.org/statistics/crude-steelproduction 0. html.

[2] GEORGE C., W., (2016): The Utilization of Slag in Civil Infrastructure Construction, Elsevier Science \& Technology, 10 .

[3] ENGSTRÖM, F., PONTIKES, Y., GEYSEN, D., JONES P.T., BJÖRKMAN, B., \& BLANPAIN, B. (2005): Review: Hot stage engineering to improve slag valorisation options, 2nd inter. slag valorization sympo., 231:251; Leuven.

[4] TAIRA, S., NAKASHIMA, K. \& MORI, K. (1993): Kinetic Behavior of Dissolution of Sintered Alumina into $\mathrm{CaO}-\mathrm{SiO}_{2}-\mathrm{Al}_{2} \mathrm{O}_{3}$ Slags, ISIJ Inter., Vol. 33, 116- 123.

[5] YU, X., POMFRET, R.J. \& COLEY, K.S. (1997): Dissolution of Alumina in Mold Fluxes, Metall. Mater. Trans. B, Vol. 28B, 275-279.

[6] AMINI, S.H., BRUNGS, M.P., JAHANSHAHI, S., \& OSTROVSKI, O. (2006): Effects of Additives and Temperature on Dissolution Rate and Diffusivity of Lime in $\mathrm{Al}_{2} \mathrm{O}_{3}-\mathrm{CaO}-\mathrm{SiO}_{2}$ Based Slags, Metall. Mater. Trans. B, Vol. 37B, 773-780.

[7] LIU, J., GUO, M., JONES, P.T., VERHAEGHE, F., BLANPAIN, B., \& WOLLANTS P. (2007): In situ observation of the direct and indirect dissolution of $\mathrm{MgO}$ particles in $\mathrm{CaO}-\mathrm{Al}_{2} \mathrm{O}_{3}-\mathrm{SiO}_{2}$-based slags, $\mathrm{J}$. Eur. Ceram. Soc. 27, 1961-1972.

[8] VALDEZ, M., PRAPAKORN, K., CRAMB, A.W., \& SRIDHAR, S. (2002): Dissolution of alumina particles in $\mathrm{CaO}-\mathrm{Al}_{2} \mathrm{O}_{3}-\mathrm{SiO}_{2}-\mathrm{MgO}$ slags, Ironmaking Steelmaking, Vol. 29 No. 1, 47-52.

[9] LEE, S.H., TSE, C., YI, K.W., MISHRA, P., CHEVRIER, V., ORRLING, C., SRIDHAR, S., \& CRAMB, A. W. (2001): Separation and dissolution of $\mathrm{Al}_{2} \mathrm{O}_{3}$ inclusions at slag/metal interfaces, J. Non-Crys. Sol. $282,41-48$.

[10] YI, K.W., TSE, C., PARK, J.-H., VALDEZ, M., CRAMB, A.W., \& SRIDHAR, S. (2003): Determination of dissolution time of $\mathrm{Al}_{2} \mathrm{O}_{3}$ and $\mathrm{MgO}$ inclusions in synthetic $\mathrm{Al}_{2} \mathrm{O}_{3}-\mathrm{CaO}-\mathrm{MgO}$ slags, Scand. J. Metall. $32,177-184$.

[11] PARK, J.-H., JUNG, I.-H., \& LEE, H.-G. (2006): Dissolution Behavior of $\mathrm{Al}_{2} \mathrm{O}_{3}$ and $\mathrm{MgO}$ Inclusions in the $\mathrm{CaO}-\mathrm{Al}_{2} \mathrm{O}_{3}-\mathrm{SiO}_{2}$ Slags: Formation of Ring-like Structure of $\mathrm{MgAl} 2 \mathrm{O} 4$ and $\mathrm{Ca} 2 \mathrm{SiO} 4$ around $\mathrm{MgO}$ Inclusions, ISIJ Inter., Vol. 46, 1626-1634.

[12] MORRIS, H. S., SAWYER, C., ZHANG, Z.T., SHANNON, G.N., NAKANOA, J., \& SRIDHAR, S. (2009): The interaction of spherical $\mathrm{Al}_{2} \mathrm{O}_{3}$ particles with molten $\mathrm{Al}_{2} \mathrm{O}_{3}-\mathrm{CaO}-\mathrm{FeOx}-\mathrm{SiO}_{2}$ slags, Fuel, Vol. 88, 670-682.

[13] ORRLING, C., SHRIDHAR, S., \& CRAMB, A.W. (2000): In-situ observation of the role of alumina particles on the crystallization behavior of slags, ISIJ inter., Vol. 40, 866-885.

[14] LVPING, F., HUAZHI, G., HUANG, A., ZHANG, M., \& LI, Z. (2015): Slag Resistance Mechanism of Lightweight Microporous Corundum Aggregate, J. Am. Ceram. Soc., Vol. 98, 1658-1663.

[15] LVPING, F., HUAZHI, G. HUANG, A., ZHANG, M., HONG, X. \& JIN, L. (2015): Possible improvements of Alumina-Magnesia castable by lightweight microporous aggregates, Ceram. Int., Vol. 41, 1263-1270.

[16] SAKO, E.Y., BRAULIO, M.A.L., LUZ, A. P., ZINNGREBE, E., \& PANDOLFELLI, V.C. (2013): Slag Resistance of $\mathrm{Al}_{2} \mathrm{O}_{3}-\mathrm{MgO}$ Refractory Castables in Different Environmental Conditions, J. Am. Ceram. Soc., Vol. 96, 3252-3257. 
[17] BATES, J. L. (1987): Heterogeneous Dissolution of Refractory Oxide in Molten Calcium-Aluminium Silicate, Comm. Am. Ceram. So., 55-57.

[18] SANDHUGE, H. K., \& YUREK, J.G. (1990): Indirect Dissolution of Sapphire into Calcia-MagnesiaAlumina-Silica Melts: Electron Microprobe Analysis of the Dissolution Process, J. Am. Ceram. Soc., Vol. 73, 3643-3649.

[19] CHOI, J.-Y., LEE, H.-G., \& KIM, J.-S. (2002): Dissolution Rate of $\mathrm{Al}_{2} \mathrm{O}_{3}$ into Molten $\mathrm{CaO}-\mathrm{SiO}_{2}-\mathrm{Al}_{2} \mathrm{O}_{3}$ Slags, ISIJ Inter., Vol. 42, 852-860.

[20] BIN, Y., XUEWEI, L.V., SHENGLIN, X., \& JIAN, X. (2016): Dissolution kinetics of $\mathrm{SiO}_{2}$ into CaO$\mathrm{Fe}_{2} \mathrm{O}_{3}-\mathrm{SiO}_{2}$ slag, Metall. mat. Trans. B, Vol 47B, 2063-2071.

[21] COOPER, A. R. JR., \& KINGERY, W. D. (1962): Dissolution in Ceramic Systems: I, Molecular Diffusion, Natural Convection, and Forced Convection Studies of Sapphire Dissolution in Calcium Aluminum Silicate, J. Am. Ceram. Soc.,Vol. 47, 37-43.

[22] SAMADDAR, B. N., KINGERY, W. D., \& COOPER, A. R. JR. (1963): Dissolution in Ceramic Systems: II, Dissolution of Alumina, Mullite, Anorthite and Silica in a Calcium-Aluminum-Silicate Slag, J. Am. Ceram. Soc., Vol. 47, 249-254.

[23] OISHI, Y., A. R. COOPER, JR., \& W. D. KINGERY (1964): Dissolution in Ceramic Systems: III, Boundary layer concentration gradients, J. Am. Ceram. Soc., Vol. 48, 88-95.

[24] BATES, J. L., (1987): Heterogeneous Dissolution of Refractory Oxides in Molten Calcium-Aluminum Silicates, J. Am. Ceram. Soc., Vol.70, 55-57.

[25] ZHANG, S., REZAIE, R. H, SARPOOLAKY, H., \& LEE, W.H. (2000): Alumina Dissolution into Silicate Slag, J. Am. Ceram. Soc., Vol. 83, 897-903.

[26] BALE, C. W., BÉLISLE, E., CHARTRAND, P., DECTEROV, S. A., ERIKSSON, G., HACK, K., JUNG, I. H., KANG, Y. B., MELANÇON, J., PELTON, A. D., ROBELIN C., \& PETERSEN, S. (2009): FactSage Thermochemical Software and Databases - Recent Developments, Calphad, vol. 33, 295-311.

[27] IMLACH, J. \& GLASSER, F.P. (1973): Sub-Solidus Relations in the System $\mathrm{CaO}-\mathrm{Al}_{2} \mathrm{O}_{3}-\mathrm{Fe}_{-}-\mathrm{Fe}_{2} \mathrm{O}_{3}$, Trans. J. Br. Ceram. Soc., Vol.72, 221-228.

[28] KIRKALDY J.S. \& BROWN L.C. (1963): Diffusion behavior in Ternary, Multiphase systems, Can. J. Met. Mat. Sc., 2:1, 89-115.

[29] VAN LOO F. J. J. (1990): Multiphase diffusion in Binary and Ternary solid-state systems, Prog. Soild St. Chem., Vol 20, 47-99.

[30] KOROS P.J. \& KING T.B. (1962): The self -diffusion of Oxygen in Lime-Silica-Alumina slag, Trans. Metall. Soc. AIME, Vol. 224, 229-306.

[31] DURINCK D., ENGSTRöM F., ARNOUT S., HEULENS J., JONES P.T., BJöRKMAN B., BLANPAIN B. \& WOLLANTS P. (2008): Hot stage processing of metallurgical slags, Resour. Conserv. Recy., Vol. 52, 1121-31. 